\title{
Marka Nefreti ve Olası Sonuçları Üzerinde İşletme Telafi Süreçlerinin Düzenleyici Etkisi
}

DOI: $10.26466 /$ opus.676294

\author{
* \\ Müge Örs* - Melis Kaytaz Yiğit ** \\ * Dr. Öğretim Üyesi, İstanbul Aydın Üniversitesi, İ.̇.B.B.F, İstanbul / Türkiye \\ E-Posta: mugeors@aydin.edu.tr \\ ORCID: 0000-0001-6415-455X \\ ** Dr. Öğretim Üyesi, Avrasya Üniversitesi, Uygulamalı Bilimler Yüksek Okulu, Trabzon/ Türkiye \\ E-Posta: melis.yigit@avrasya.edu.tr \\ ORCID: 0000-0001-7036-166X
}

$\ddot{O} z$

Literatürde az sayıda çalışma olması nedeniyle, çalışmamızda marka aşkı kavramının zıddı olan marka nefreti kavramı incelenmiş ve marka nefreti ile olası sonuçları arasında (marka reddi, negatif WOM, marka öcü) işletmelerin telafi süreçlerinin (tazmin, özür dileme, kendini ifade edebilme) düzenleyici bir etkisi olup olmayacă̆̆ araştırılmıştır. Çalışma, kantitatif tanımsal bir araştırma olup, çalışmada marka nefreti yaşamış 213 tüketiciye ulaşılmıştır. Kolayda örnekleme yöntemi kullanılan araştırmada, elde edilen veriler, Açıklayıcı ve Doğrulayııı Faktör analizi, Yol Analizi gibi ileri bazı analiz yöntemleri ile SPSS 19 ve AMOS 23 paket programları kullanılarak veri analizine tabi tutulmuştur.

Çalışmanın bulgularına göre, tercih ettiği marka ile nefret boyutuna gelmiş negatif bir ilişki yaşayan tüketicilerde, strasıly marka ile ilgili etrafindaki kişilere negatif yönde iletişim yapma (nWOM), markayı reddetme ve markanın ürün velveya hizmetlerine karşı bilinçli bir şekilde zarar verme eğilimi olarak adlandırılan markadan öc alma durumlarının geliştiği görülmüştür. Bununla birlikte işletmelerin ortaya koydukları tazmin, özür dileme ve kendini ifade edebilme telafi stratejilerinin, marka nefreti yaşayan tüketicilerin ortaya koydukları reddetme, öc alma veya negatif iletişim yapma davranışlarının azalmasında herhangi bir etkisi olmadığı görülmüş̧ür. Buradan hareketle ortaya çıkan sonuç tüketicinin nefret boyutunda bir iliş̧ki yaşadı̆̆ı markadan, ne türlü bir telafi hizmeti alırsa alsın, kuvvetli bir negatif duygu olan nefretin süreçte hakim geldiği ve müşteriyi eski tutumuna döndüremediği yönündedir.

Anahtar Kelimeler: Marka nefreti, marka reddi, marka öcü, nWOM, telafi stratejileri 


\title{
Moderation Effect Of Recovery Strategies On The Relationship Between Brand Hate And Its Possible Outcomes
}

\begin{abstract}
Due to the limited number of studies in the literature, in this study, the concept of brand hate and its possible outcomes (brand rejection, negative word of mouth, retaliation) were examined in the moderation effect of recovery strategies (apology, compensation and voice). The study is a quantitative descriptive study and it is reached to 213 consumers who had hate relationship with brands. Convinient sampling method was used and the data obtained were subjected to data analysis such as Explanatory, Confirmatory Factor analysis and Path Analysis, using statistical package programme of SPSS 19 and AMOS 23. The findings of the study indicate that consumers who have a brand hate are showing respectively a negative word of mouth, brand rejection and brand retaliation. In addition, it is revealed that recovery strategies (apology, compensation and voice) put forward by companies are not be able to decrease the relationship between brand hate and brand rejection, retaliation or negative word of mouth (nWOM) From this point of view, it is seen that no matter what kind of compensation service the consumer receives from the hated brand prevails in the process (as hate is the strongest negative emotion) and is unable to return the customer to his former attitude.
\end{abstract}

Keywords: Brand Hate, brand rejection, brand retaliation, nWOM, recovery strategies 


\section{Giriş}

Pazarlamadaki marka literatüründe, markalara yönelik olumlu duygular üzerinde önemli araştırmalar bulunmaktadır. Araştırmaların \%98'i pozitif duygular üzerinde dururken, tüketicilerin genellikle markalarla nasıl aşk yaşadıkları araştıılmaktadır (Bagozzi ve Yi, 1988; Laros ve Steenkamp, 2005; Carroll ve Ahuvia, 2006; Albert, Merunka ve Valette, 2008; Batra, Ahuvia ve Bagozzi, 2012; Fetscherin ve Heinrich, 2014). Marka ile aşk yaşayan pek çok tüketicinin daha sadık, marka ile ilgili pozitif yorum yapmaya daha gönüllü ve negatif bilgilere karşı çok daha fazla dirençli olduğu ortaya konulmaktadır (Batra vd., 2012).

Sadece çok az sayıda çalışma markalara olan negatif duygulardan bahsetmektedir (Dalli, Romani ve Gistri, 2006; Fournier ve Alvarez, 2013; Romani vd., 2012; Sarkar ve Sreejesh, 2014). İlginçtir ki markalara karşı beslenen kuvvetli pozitif duygular birdenbire markadan şiddetle hoşlanmama gibi negatif bir duyguya da bürünebilir (Johnson, Matear ve Thomson, 2011). Literatürde çok az sayıda çalışma bu durumun nedenini ortaya koymakla birlikte, ilgili durumun yaratacağı çıktıları inceleyen daha da az sayıda çalışma bulunmaktadır.

Tüketicilerin bazıları belirli markalara sevgi hissederken, diğerleri markalara karşı kayıtsız kalabilir veya bazıları belirli markalardan nefret edebilirler (Khan ve Lee, 2014). Romani ve arkadaşları (2012), tüketicilerin markalarla ilgili yaşadığı olumsuz duygusal durumlara ilişkin marka araştırmalarında yetersiz bilgi söz konusu olduğunu belirtmiştir. Konuyla ilgili benzer bir argüman da Fetscherin ve Heinrich'ten gelmiş ve yazarlar özellikle tüketicimarka ilişkisinden yaşanan aşırı olumsuz duyguların bir karanlık taraf oluşturduğunu ve bu konunun daha fazla araştırmaya ihtiyaç duyulduğunu belirtmişlerdir (Fetscherin ve Heinrich, 2015, s.387).

Dolayısıyla çalışmamızda, marka nefreti kavramı ele alınmış, tüketicilerin belirli bir markaya yönelik geliştirdikleri negatif duyguların nasıl sonuçlar doğurabileceği ampirik bir çalışmayla ortaya konmuştur. Bu ilişkide başarılı bir telafi süreci veren firmaların, ilişkinin yönünü ve gücünü değiştirip değiştiremeyeceği araştırılmıştır. Çalışmanın teorik önemi literatürde az sayıda benzer çalışma olması olup, pratik önemi ise özellikle pazarlama pratisyenlerine marka nefretinin olası sonuçlarının telafisinde ne tarz stratejiler geliştirilebileceği ile ilgili yardımcı olmasıdır. 


\section{Marka Nefreti Kavramı ve Teorik Altyapısı}

Literatürde nefret kavram1, bazen bir motivasyon (Rempel ve Burris, 2005) bazen bir duygu (Weingarten, 2006) bazen de bir tutum olarak ele alınmıştır (Ben-Ze'ev, 2000). Dolayısıyla kavramla ilgili kullanılan genel bir tanım bulunmamaktadır. Pek çok yazarın üzerinde ortak görüş sunduğu bir konu vardır ki, o da nefretin, durağan ve uzun dönemli bir duygu olduğudur (BenZe'ev, 2000; Royzman, 2004; Rempel ve Burris, 2005; Weingarten, 2006).

Weingarten (2006)'a göre nefret her zaman bir obje ve subjeye yönlendirilmektedir. Rempel ve Burris (2005, s.300) nefret kavramını, diğer objelerin iyiliğini azaltmak ya da yok etmek amaciyla ortaya konan bir motivasyon olarak görmektedirler. Ben-Ze'ev (2000, s.381) ise nefreti uzun dönemli bir his olarak tanımlamakta ve nefreti, nesneye yönlendirilen doğal ve tehlikeli hislere sahip olmak olarak açılamaktadır. Literatürde sıkça kullanılan Sternberg' in aşk üçgeni teorisi (the triangular theory of love) de nefrete uyarlanmış ve nefreti, farklı durumlarda farklı şekillerde çoklu yönleri olabilen bir kavram olarak tanımlanmıştır (Sternberg, 2003, s.306). Aşk üçgeni teorisi, nefret üçgenine uyarlandığında, nefretin üç boyutu; bıkkınlık, korku-kızgınlık, devalüasyon-kayıp olarak adlandırılmıştır (Sternberg, 1986). Yazar bunlara ek olarak, aşk ve nefret spektrumunu oluşturmuş ve derecelendirmede iki uç köşeye nefret ve aşkı koyarak bu iki duygunun arasına sırasıyla gönülsüzlük, sevmeme, saygı duymama, nötr olma, ilgi duyma, beğenme, isteme gibi duygularını da eklemiştir (Sternberg, 1986).

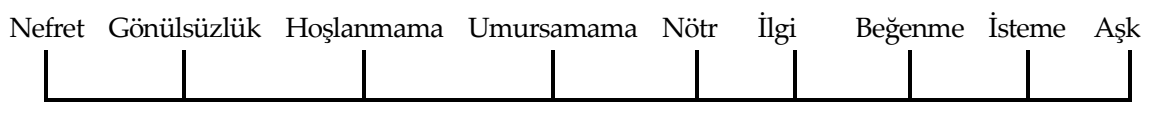

Şekil 1. Aşk ve Nefret Spekturumu

Çalışmamız marka nefreti ile ilgili olduğu için konu aşktan ziyade nefret üzerinde durularak incelenecektir. Nefret ile ilgili yapılan çalışmalarda, Fehr ve Russell (1984) tüketicinin yaşadığı duyguların protiplerini oluşturmuş ve aşktan sonra en güçlü duygunun ikinci sırada nefret olduğunu ortaya koymuştur. Benzer sonuçlara ulaşan Shaver ve arkadaşları da (1987), tüketici tarafından tanımlanan 213 duygu arasında, nefreti 3. sırada güçlü bir duygu 
olarak sıralamıştır. Zarantonello ve arkadaşları (2016, s.14) ise gerçekleştirdikleri çalışmada tüketicilerin yaşadığı negatif duyguları, kızgınlık, bıkkınlık, hayal kırıklığı, utanma ve kaçınma gibi duygular olarak tanımlamış ve bu duyguları pasif ve aktif marka nefreti olarak sınıflandırmışlardır.

Pazarlama literatüründe marka nefreti kavramı, Sternberg'in geliştirdiği aşk ve nefret spekturumu baz alınarak, markadan hoşlanmama (brand dislike) ve marka nefreti (brand hate) gibi terimlerle isimlendirilmektedir. Literatüre ilk kez marka nefreti kavramını Grégoire ve arkadaşları (2009) tarafından kazandırılmış olup, yazarlar marka nefretini, markadan öç almak için duyulan nefret veya markadan kaçınma duygusu olarak tanımlamıştır. Romani ve arkadaşları (2009) ise marka nefreti kavramını, tüketicinin markaya yönelik geliştirdiği sevmeme, kızgınlık, mutsuzluk gibi negatif hisler olduğunu belirtmiş olup, Dali ve arkadaşları da (2007) marka nefretini, markayı sevmeme ekseninde değerlendirmiştir. Yazarlar, markanın ürün özelliklerinin, kalitesinin, fiyatının, ürünün kullanıcı profilinin marka nefreti yaratabileceğini belirtirken, tüketicinin markayı etik- ahlak dışı veya yasa dışı algılamasının da marka nefretine neden olabileceğini belirtmişlerdir.

Alba ve Lutz (2013) marka nefretini gerçek bir marka bıkkınlığı olarak tanımlamışlar, firmaların değişim maliyetlerinin yüksek olması, pazarda yerel bir monopoli oluşturmaları ya da yeni oyuncuların pazara girişinde engel yaratabilecek politikalarının varlığının tüketicide marka nefreti doğurabileceğini ortaya koymaktadırlar. Yazarlar marka nefreti yaşayan tüketicilerin sosyal medyada duygularını açıkça ifade ettiklerini, bu tarz nefret söylemlerini belirli web siteleri ve şikâyet forumlarında paylaşmaktan çekinmediklerini iletmektedir. Kısaca markadan nefret eden tüketiciler, günlük olarak diğer tüketicilerin de bulundukları pek çok sanal ve sosyal ortamda paylaşım yapmaktadırlar.

Bryson ve arkadaşları (2013) ise marka nefretini jenerik bir terim olarak "Bir markaya karşı duyulan yoğun negatif hisler" olarak tanımlamaktadır. Yazarlar genellikle marka nefretini oluşturan öğelerin, ülke menşei etkisi, ürün veya hizmetle ilgili yaşanan müşteri memnuniyetsizliği, ürünü kullanan negatif kullanıcı stereotipileri ve kurumun zayıf sosyal performans anlayışı olduğunu ileri sürmektedirler. Bu nedenlerin de negatif ağızdan ağıza iletişim yarattı̆̆ını, boykot veya sabote etme gibi davranışlarla sonuçlandığı açiklamaktadırlar (2013, s. 395). 
Pazarlama literatüründe, marka nefreti ile ilişkilendirilebilecek çalışmalar genellikle üç ana çalışma başlığı altında toplanmaktadır. İlki tüketici ile marka arasında yaşanan negatif ilişkileri ele alan çalışmalardır (Fournier ve Alvarez, 2013; Park, Eisingerich ve Park, 2013). İkincisi, marka karşıtı topluluklarının üzerine yapılan çalışmalardır ki bunlar genellikle tüketicilerin marka ile yaşadıkları negatif hisler doğrultusunda bir araya toplanıp, negatif deneyimlerini diğer tüketicilerle paylaştıkları ve hatta ortak bir aksiyon planı belirledikleri görüşünü ortaya koyar (Hollenbeck ve Zinkhan, 2010; Krishnamurthy ve Küçük, 2009). Üçüncüsü ise özellikle hizmet pazarlamasında tüketicilerin hizmet sağlayıcıları ile yaşadıkları negatif deneyimler sonucunda oluşan hizmet hataların içeren çalışmalardır (Grégoire, Tripp ve Legoux, 2009; Johnson, Matear ve Thomson, 2011).

Tüketici ile negatif marka ilişkilerine odaklanan pek çok çalışma konuyu, tüketmeme (anti-consumption) (Hogg, 1998; Cherrier, 2009; Cromie ve Ewing, 2009; Iyer ve Muncy, 2009), sadakatsizlik (anti-loyalty) (Rindell, Strandvik ve Wilén, 2014) veya boykot etme (Yüksel ve Mryteza, 2009), markadan kaçınma (brand avoidance) (Lee, Motion ve Conroy, 2009; Liao Chou ve Lin, 2015), markayı reddetme (Sandikci ve Ekici, 2009; Nenycz-Thiel ve Romaniuk, 2011), marka karşıtlığ (brand opposition) (Wolter, Brach, Cronin ve Bonn, 2016), anti-markalaşma, anti-branding (Romani vd., 2012), Dessart, Morgan-Thomas ve Veloutsou, 2016), markayı sevmeme (Dalli vd., 2007; Romani vd., 2009) veya marka nefreti (Küçük, 2008; Krishnamurthy ve Küçük, 2009; Bryson, Atwal ve Hultén, 2013; Zarantonello, Romani, Grappi ve Bagozzi, 2016) perspektiflerinden incelemektedirler.

\section{Marka Nefretinin Olası Sonuçları}

Marka nefreti üzerine yapılan araştırmalarda marka nefreti, pasif marka nefreti (markadan kaçınma, markayı değiştirme) ve aktif marka nefreti (negatif ağızdan ağıza iletişim ve marka öcü) olarak sınıflandırılmıştır (Hegner, Fetscherin ve Delzen, 2017). Çalışmamızda hem aktif hem de pasif marka nefreti sonuçları incelenmektedir. 


\section{Markayı reddetme (Brand Rejection)}

Önceki araştırmaların elde ettiği bulgulara göre, tüketiciler ile markaların arasındaki ilişkinin yakınlığı, tüketicilerin markalara duygusal olarak verdikleri tepkiler ve o marka ile ilgili ne hissettikleri olarak tanımlanmaktadır (Monga, 2002; Breivik ve Thorbjørnsen, 2008). Sternberg (1986, s: 119), aşk ilişkilerinin duygusal temeli olan samimiyetin "yakınlık, bağlanma ve bağlılık duyguları" ile ifade edileceğini ileri sürmektedir. Markaya yönelik gelişen pozitif duygu ve hislere benzer olarak, tüketici markaya negatif hisler beslediği zaman, bu hislerin sonucunda da uzaklaşma ve kaçınma durumunun yaşandığı bilinmektedir. Dolayısıyla marka kaçınması, tüketicilerin bilinçli olarak bir markadan uzak durmayı veya onu reddetmeyi seçtiği durumlarda ortaya çıkmaktadır (Grégoire vd., 2009; Lee vd., 2009, Park vd., 2013; Zarantonello, Romani, Grappi ve Bagozzi, 2016)

Hirschman'ın (1970) çıkış teorisine göre, mutsuz müşteri sesini çıkartarak memnuniyetsizliğini ifade edebileceği gibi, ilgili markayla olan ilişkisini sonlandırarak da tepki verebilir. Bu bağlamda çıkıs, tüketicinin markayı bir daha satın almamak üzere marka ile olan ilişkisini sonlandırılmasıdır (Hirschman, 1970). Bununla birlikte markayı reddetmek, markadan çıkmaktan daha güçlü bir kavramdır ve tüketicinin kasten ve bilinçli bir şekilde markayı bırakmayı onaylaması durumunda görünür (Lee vd., 2009, s:170). Genelde literatürde marka reddi, marka değiştirme ile eş anlamlı olarak kullanılsa da (Oliva, Oliver ve MacMillan, 1992), marka değiştirme sadece rakibin daha iyi bir teklif sunmasıyla gerçekleşmektedir (Lee vd., 2009). Bu nedenle çalışmamızda markayı reddetme marka nefretine giden tek pasif neden olarak ele alınmış ve bir sonraki aşaması olan marka değiştirme değişkeni modele eklenmemiştir.

Lee ve arkadaşları (2009), tüketicilerin marka reddetmesi veya kaçınması yaşama durumununum temel nedenlerini; tüketicilerin ürün ve hizmetlerle yaşadığı negatif deneyimlere, markayla yaşanan kimlik uyumsuzluklarına, tüketicinin ödediği bedel karşısında aldığı faydayı değerlendirirken yaşadığ fayda-maliyet eksikliğine ve marka ile etik ve ideolojik uyumsuzluğa bağlamaktadır.

- H1: Marka nefreti ile marka reddi arasında anlamlı bir ilişki vardır. 


\section{Negatif Ă̆ızdan Ă̆ıza İletişim Kurma (Negatif WOM)}

Negatif WOM, tüketicinin ürün veya hizmetlerle ilgili yaşadığı negatif deneyimleri kötüleyecek şekilde etrafiyla paylaşması olarak tanımlanmaktadır. Tüketici bu negatif deneyimleri etrafındakilerle paylaştığında ilgili firmanın ününü lekeleyeceğini ve etrafındaki kişilerin de o firma ile olan ilişkilerini yeniden gözden geçireceğini düşünmektedir (Singh, 1988). Tüketicilerin negatif deneyimlerini pozitif deneyimlerine kıyasla paylaşmakta daha istekli olduğu da bilinmektedir (Singh, 1988; Baumeister, Bratslavsky, Finkenauer ve Vohs, 2001).

Üçüncü parti şikayetleri olarak da tanımlanan, tüketicilerin negatif duygularını medya, tüketici kurumları ve ajansları, yasal bazı tüketici dernekleri gibi belirli organizasyonlarla paylaşmaları, tüketicinin marka nefreti yaşadığı firmanın ceza almasını sağlamak veya yaşadığı probleme çözüm aramakla ilgili olduğu bilinmektedir (Singh, 1988).

Literatürde ikiye ayrılan tüketicinin şikayet etme davranışı kişisel ve kamusal şikayetler olarak sınıflandırılmıştır. (Nyer ve Gopinath, 2005; Christodoulides, Jevons ve Bonhomme, 2012; Presi, Saridakis ve Hartmans, 2014). Kişisel şikayetler tüketicinin bir marka ile ilgili arkadaşlarına ailesine ya da yakın çevresindekilere negatif yaptığı yorumlar paylaşımlar iken, kamusal şikayetler bu negatif yorum ve paylaşımları bloglarda, web sitelerinde ve/veya sosyal medya ortamlarında paylaşmasıdır (Zeithaml, Berry ve Parasuraman, 1996).

Kişisel ve kamusal şikayetler çalışmamızda ayrı ayrı değişkenler olarak değil, özellikle marka nefreti gibi marka ile yaşanılan negatif ilişkilerde, önemli bir çıktı olan negatif wom başlı̆̆ 1 altında tek bir değişken olarak incelenecektir (Ruiz-Mafe, Aldaz Manzano, Veloutsou, 2015; Zarantonello vd., 2016; Hegner vd., 2017).

- $\mathrm{H}_{2}$ : Marka nefreti ile negatif ağızdan ağıza iletişim kurma (NWOM) arasında anlamlı bir ilişki vardır.

\section{Marka Öcü (Brand Retalitation)}

Marka öcü, marka nefretinin en güçlü çıktılarından biridir. Bu tarz çıtılar, tüketiciler marka ile ilgili aktif ve direkt olarak harekete geçmek istediklerinde oluşmaktadır (Sampedro, 2017, s: 27). Grégoire ve arkadaşları (2010) 
marka öcünü marka nefretinin bir çıtısı olarak tanımlamakta ve Sternberg (2003) ise marka nefretinin öç alma güdüsünden beslendiğini ifade etmektedir.

Grégoire ve arkadaşları (2010) tüketicilerin, markaların onlara yaşattıkları zarar karşısında, markalardan öç almak için, onları cezalandırmak ve bilinçli bir şekilde zarar vermek istediklerinden bahsetmektedir.

- H3: Marka nefreti ile marka öcü arasında anlamlı bir ilişki vardır.

\section{Telafi Stratejileri}

Tüketicilerde bağışlama meydana geldiğinde, nefret ettiği markaya karşı hissettikleri negatif düşünceler, hisler ve davranışlar azabilmektedir (McCullough ve diğerleri, 2000; Worthington, 2005) ve tüketiciler daha az negatif WOM yayma eğiliminde olmaktadırlar (Tsarenko ve Tojib, 2011).

Pazarlamada tüketicinin bağışlaması, kendisine sunulan telafi stratejileri ile mümkündür. Telafi stratejileri firmaların ürün veya hizmetleri ile ilgili tüketicilerine yaşattıkları bazı eksikler, hatalar ya da sekteler söz konusu olduğunda ortaya çıkmaktadır (Gronroos, 2000; Johnston ve Mehra, 2002). Telafi stratejileri genellikle özür dileme (apology), tazmin etme (compensation) veya kendini ifade edebilme (voice) şeklinde şekillenmektedir (Hui ve $\mathrm{Au}$, 2001). Yaşanılan sıkıntı karşısında bunlardan herhangi birinin uygulanması tüketicinin negatif duygularını ortadan kaldırabilmektedir (Bitner, Booms ve Tetreault, 1990).

Tazmin Etme: Tazmin etme, uygun ve en çok kullanılan bir telafi stratejisi olarak literatürde yerini almaktadır (Hoffman, Kelley ve Chung, 2003, Inyang, 2015, Baruönü Latif ve Uslu, 2019). Tazmin etme stratejisi, firmaların bir tazmin çeşidi olarak ekonomik bazı çözüm yollarına başvurmasıdır (Smith ve diğerleri, 1999). Bu strateji genellikle alışveriş ortamında bir taraf diğer taraf karşısında eşit olmayan bir şekilde haksızlığa uğratılırsa veya incitilirse ortaya çıkmaktadır (Walster, Berscheid ve Walster, 1973). Ekonomik tazmin, tüketicinin ürün veya hizmete ödediği bedelin bir kısmını ya da tamamını geri ödemek olabileceği gibi sonraki satın almaları için ekstra bir indirim ya da ek bir ürün hediye etmek de olabilir (Hui ve $A u, 2001$ ). Firmaların müşterilerine uygun bir tazmin teklif etmesi müşterilerine gösterdikleri bir 
saygı olarak algılanmakta (Conlon ve Murray, 1996) ve oluşabilecek kayıpların engellenmesi için bir teşebbüs olarak görülmektedir. (Walster vd. 1973; Tax Brown ve Chandrashekaran, 1998; Gelbrich, Gathke ve Gregoire, 2013, Baruönü Latif ve Uslu, 2019). Yapılan araştırmalar finansal tazminin tüketicilerin bağlılığını desteklediğini göstermektedir (Vazques-Casielles, Iglesias ve Varela-Neira, 2012, Hsu vd., 2017).

- $\mathrm{H}_{4}$ : Marka nefreti ile marka reddi arasındaki ilişkide tazmin etme telafi stratejisinin düzenleyici etkisi vardır.

- H5: Marka nefreti ile negatif ağızdan ağıza iletişim kurma (NWOM) arasındaki ilişkide tazmin etme telafi stratejisinin düzenleyici etkisi vardir.

- $\mathrm{H}_{6}$ : Marka nefreti ile marka öcü arasındaki ilişkide tazmin etme telafi stratejisinin düzenleyici etkisi vardır.

Özür Dileme: Özür dileme telafi stratejisi ile firmalar sorumluluğu kabul etmekte ve samimi pişmanlıklarını tüketicisine iletmektedirler (Conlon ve Murray, 1996; Blodgett Granbois ve Walters, 1993; Casidy ve Shin, 2015). Barlow ve Moller'a göre özür dileme, firmanın yaşanan negatif bir durum karşısinda özrünü dile getirmesidir (Barlow ve Moller, 1996). Telafi stratejilerinden özür dileme, özellikle hizmet hatalarında tüketicinin deneyimlediği negatif olayları bertaraf etmek için, firmaların tüketiciyle nazik bir iletişim kurması, tüketicisine kibarlık ve nezaket göstermesi ve onlarla ilgilenip, onlara empati göstermesidir (Hart, Heskett ve Sasser, 1990; Kelly, Hoffman ve Davis, 1993; Smith, Bolton ve Wagner, 1999, Baruonu Latif ve Uslu, 2019).

- H: Marka nefreti ile marka reddi arasındaki ilişkide özür dileme telafi stratejisinin düzenleyici etkisi vardır.

- Hs: Marka nefreti ile negatif ağızdan ağıza iletişim kurma (NWOM) arasındaki ilişkide özür dileme telafi stratejisinin düzenleyici etkisi vardır.

- H9: Marka nefreti ile marka öcü arasındaki ilişkide özür dileme telafi stratejisinin düzenleyici etkisi vardır.

Kendini ifade edebilme: Kendini ifade edebilme (voice) müşterinin suçlu olarak gördüğü firmaya kendisini ifade edebilmesidir (Hui ve $\mathrm{Au}, 2001$ ). Goodwin ve Ross kendini ifade edebilmenin hem fonksiyonel hem de değeryaratan faydası olduğundan bahsetmektedir (Goodwin ve Ross, 1992). Aldığı 
ürün veya hizmet bağlamında sorun yaşayan tüketicilerin firmalar tarafından dinlenmesi telafi stratejisi anlamında tüketicinin yaşadığı negatif duyguları azaltmaktadır (Walker, 2018). Bu süreçte firmalar müşterilerine hiç müdahale etmeden onları kesintisiz dinlemeleri gerekmektedir (Cottle, 1990). Bu durum kişilerin yaşadığı stres etkilerini azaltıp, duygusal dengelerini yeniden geri kazanmalarına neden olmaktadır. Benett'in yaptığı bir araştırmaya göre, yaşadıkları sıkıntıyı dile getirmesine müsaade edilen müşterilerin \%82'sinin (Üstelik sadece \%12'sinin şikâyeti ile mükemmel bir şekilde ilgilenildiğini ve \%18'inin de oldukça iyi ilgilenildiğini ifade etmesine rağmen) firmadan yine aynı miktarda satın alma gerçekleştirdiği görülmektedir (Benett, 1997).

- H10: Marka nefreti ile marka reddi arasındaki ilişkide kendini ifade edebilme telafi stratejisinin düzenleyici etkisi vardır.

- H11: Marka nefreti ile negatif ağızdan ağıza iletişim kurma (NWOM) arasındaki ilişkide kendini ifade edebilme telafi stratejisinin düzenleyici etkisi vardır.

- H12: Marka nefreti ile marka öcü arasındaki ilişkide kendini ifade edebilme telafi stratejisinin düzenleyici etkisi vardır.

\section{Araştırma}

\section{Araştırmanın amact ve önemi}

Ulusal ve uluslararası pazarlama literatürüne bakıldığında marka aşkı konusunun sıklıkla çalışılan popüler bir konu olduğu bununla birlikte marka nefreti konusunun ise daha bakir kaldığ ve pek ele alınmadığ görülmektedir. Araştırmanın amacı marka nefreti kavramının olası sonuçlarını literatür ışığında incelemek ve bu ilişkide firmaların güdebileceği telafi süreçlerinin aracı etkisini ölçümlemektedir. Araştırmanın teorik önemi telafi stratejileri bağlamında konunun ilk kez ele alınması olması ile birlikte, pratik önemi ise pazarlama profesyonellerine marka nefreti kavramının tüketicide yarattı̆ 1 olası sonuçları göstermek ve bu negatif çıtıları yönetebilmek anlamında aktif ve/veya marka nefreti yaratmamak bağlamında proaktif stratejiler geliştirmenin önemine vurgu yapmaktır. 


\section{Araştırma Metodolojisi}

Araştırma kantitatif tanımsal bir araştırma olup, araştırmada bütçe ve zaman kısıtı nedeniyle tesadüfi olmayan bir örneklemi metodu olan kolayda örnekleme yöntemi seçilmiştir. Araştırmada veri toplama yöntemi olarak online anket tercih edilmiş olup, eksik verilerin ve uç değerlerin ayıklanma aşamasindan sonra toplam 213 adet anket veri analizine tabi tutulmuştur. Anketler İstanbul ilinde toplanmıştır. Çalışmanın ana kütlesini bir markayla negatif bir deneyim yaşamış ve o markaya karşı nefret duygusu geliştirmiş tüketiciler oluşturmaktadır. İlgili tüketicilerin toplam sayısını bilmek imkansız olduğundan örneklem büyüklüğü hesaplamalarında, araştırma modeli ve hipotezleri doğrultusunda kullanılacak veri analizlerinin yapılabilmesi için gerekli olan eşik koşulların üzerinde veri toplanmasına dikkat edilmiştir. Pallant'a göre (2013), çoklu regresyon analizine tabi tutulacak verinin örneklem büyuiklügü hesaplanamasında, genellenebilirlik sorunu yașamamak için $\mathrm{N}>$ $50+8 \mathrm{~m}$ formulü kullanılmaktadır. Formulde $\mathrm{N}$ degeri, örneklem büyuiklügünü, $m$ değeri ise bağmsız değss,ken sayısını ifade etmektedir (Tabachnick ve Fidell, 2007). Bu formule göre dört bağmsız degiss,kene sahip olan araș,tırma modelinde öneklem büyuiklügünün $(\mathrm{N}>50+8 \mathrm{~m}=\mathrm{N}>50+32=$ 82) sekseniki katılımcıdan fazla olması gerektiğ ortaya çımaktadır. Bununla birlikte çalışmada veri analizinde kullanılan Dogrulayıc Faktör Analizi, Geçerlilik Analizi ve Yol Analizleri ölçümleri için kullanılan Yapısal Eșitlik Modellemesi yönteminde de Hoelter's Index'e göre örneklem büyuiklügü mutlaka 200'ün üzerinde olmalıdır (Byrne, 2010). Çalışmada ilgili eşik değerlerin üzerinde toplam 213 adet veri toplanmış ve analize tabi tutulmuştur.

Çalışmada anket formu beş farklı bölümden oluşmaktadır. İlk bölüm katılımcıların demografik özelliklerini ölçmeye yarayan cinsiyet, yaş, gelir grubu, eğitim, medeni durum ve meslek soruların içermektedir. Diğer bölümlerde ise sırasıyla marka nefreti, marka reddi, negatif ağızdan ağıza iletişim (nWOM) ve marka öcü ile ilgili sorular sıralanmaktadır. Marka nefreti, ölçeği Lee ve arkadaşlarının (2009) çalışmasından beş soru şeklinde adapte edilmiştir. Modelin çıktı değişkenleri olan marka reddi, negatif ağızdan ağıza iletişim (nWOM) ve marka öcü ise Romani ve arkadaşlarının (2012) ve Thomson ve arkadaşlarının (2012) çalışmalarından adapte edilmiştir. Marka reddi ölçeği üç sorudan, negatif ağızdan ağıza iletişim (nWOM) ölçeği ve marka 
öcü ölçeği ise dörter sorudan oluşmaktadır. Üç̧ farklı boyuttan oluşan (Tazmin etme, kendini ifade etme ve özür dileme) telafi ölçeği ise Walker'ın 2018 yılında yaptığı çalışmasından elde edilmiştir. Ölçeğin tazmin boyutu üç, kendini ifade etme boyutu beş, özür dileme boyutu ise üç sorudan oluşmaktadır. Veri 5'li likert tipi ölçek aracilığıyla toplanmıştır. Araştırmanın verileri SPSS 19 ve Amos 22 veri analizi programlan kullanılarak analize tabi tutulmuş olup, veriler üzerine Açılayıı Faktör Analizi, Doğrulayıc Faktör Analizi, Yapısal Eşitlik Yol Analizi ve aracı değişken (Moderation) analizi gerçekleştirilmiştir. Araştırmanın modeli aşağıdaki gibidir.

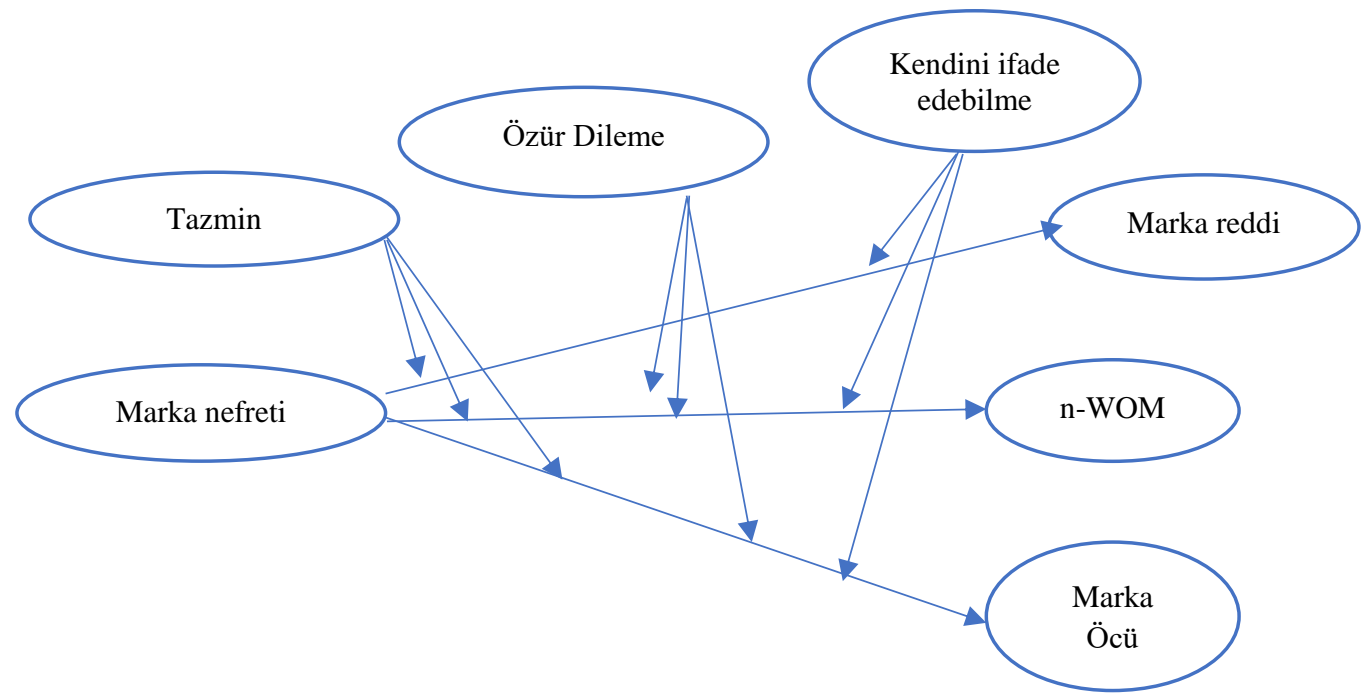

Şekil 2. Marka nefreti ve olası sonuçları üzerinde işletme telafi süreçlerinin düzenleyici etkisi

\section{Bulgular}

\section{Tanımlayıcı İstatistikler}

Araştırmaya katılan toplam 213 kişinin katılımcıların 131'i (\%61,5) kadın, 82 ise erkektir $(\% 38,5)$. Genel olarak genç ve orta yaş grubuna sahip olan katılımcların 82'si (\%38,5) 26-34 yaş aralığında olup, 67'si (\%31,5) 35-44 yaş aralığındadır. Katılımcların büyük çoğunluğu 85 kişi ile $(\% 39,9)$ özel sektör çalışanı olup, özel sektör çalışanlarını sırasıyla, 45 çalışmayan ( \%21,1), 33 kamu 
çalışanı (\%15,5), 25 serbest meslek sahibi ( \%11,7) , 16 öğrenci $(\% 7,5)$ ve 9 emekli $(\% 4,2)$ olan katılımcı grupları izlemektedir. Katılımcıların 128'i evli, 85'i bekar olup, ağırlıklı olarak üniversite (84 kişi, \%39,4) ve lise mezunu (60 kişi, \%28,2) kişilerden oluşmaktadır. Gelir grupları incelendiğinde katılımc1lardan 68 kişinin en yüksek yüzde ile (\%31,9) 3.501-5000 TL gelir grubuna ait olduğu görülmektedir (Tablo 1).

Tablo 1. Katılımcılarn Demografik Özellikleri

\begin{tabular}{|c|c|c|c|c|c|}
\hline Değişkenler & Say1 & Yüzde & Değişkenler & Sayı & Yüzde \\
\hline Cinsiyet & & & Eğitim Durumu & & \\
\hline Kadın & 131 & 61,5 & İlköğretim & 4 & 1,9 \\
\hline Erkek & 82 & 38,5 & Lise & 60 & 28,2 \\
\hline Yaş aralığı & & & Ön lisans & 20 & 9,4 \\
\hline 18 yaş ve altı & 1 & 0,5 & Lisans & 84 & 39,4 \\
\hline $19-25$ & 37 & 17,4 & Lisansüstü & 45 & 21,1 \\
\hline $26-34$ & 82 & 38,5 & Hane Geliri & & \\
\hline $35-44$ & 67 & 31,5 & 2020 TL ve altı & 8 & 3,8 \\
\hline 45 yaş ve üstü & 26 & 12,2 & $2021-3500 \mathrm{TL}$ & 57 & 26,8 \\
\hline Meslek & & & 3501 TL- 5000 TL & 68 & 31,9 \\
\hline Öğrenci & 16 & 7,5 & $5001-7000 \mathrm{TL}$ & 44 & 20,7 \\
\hline Özel Sektör & 85 & 39,9 & 7001 TL ve üstü & 36 & 16,9 \\
\hline Kamu çalışanı & 33 & 15,5 & Total & 213 & 100 \\
\hline Serbest Meslek & 25 & 11,7 & & & \\
\hline Emekli & 9 & 4,2 & & & \\
\hline İşsiz/Çalışmıyor & 45 & 21,1 & & & \\
\hline \multicolumn{6}{|l|}{ Medeni Durum } \\
\hline Evli & 128 & 60,1 & & & \\
\hline Bekar & 85 & 39,9 & & & \\
\hline
\end{tabular}

\section{Varsayimlar}

Veri analizi öncesinde verinin tamamının uç değer ve eksik değer kontrolleri gerçekleştirilmiş ve veri ileri analiz teknikleri uygulayabilmek anlamında hazır hale getirilmiştir. Veriye parametrik testler uygulayabilmek için verinin normal dağılım göstermesi gerekmektedir (Sipahi ve diğerleri, 2010). Değsskenlerin maksimum ve minimum çarpıklık değerlerine bakılmıs, ve tüm verinin çarpıklık degerlerinin -1,116 ile 0,692 aralığnda, basıklık degerlerinin ise, -1,122 ile 0,919 aralığnda dagı̆ldığ görulmüsștür. Degisskenlerin çarpıklık (Skewness) ve basıklık (Kurtosis) degerlerinin genel olarak 10 değerinin altında olması, verinin kısmen normal dağldığ anlamına gelmektedir 
(Kleine, 2011). Araştırma modelinin diğer bir varsayımı, veriye çoklu regresyon analizi uygulanabilmesinin ön koşulu olan verinin çoklu bağntı problemi yaşayıp yaşamadığının kontrol edilmesidir. Araștırmadaki tüm bağımsız değ̌s,kenlerin Tolerans degerleri 0,1'ün üzerinde, VIF değri de 10'un altındadır (Tablo 2). Bu degerler bağmsız degısskenler arasında çoklu baglantı problemi olmadığını ve veriye çoklu regresyon uygulanabileceğini göstermektedir.

Tablo 2. Bağımsız Değişkenlerin Çoklu Bağıntı Analizi

\begin{tabular}{lcc}
\hline & Tolerans & VIF \\
\hline Marka nefreti & 0,975 & 1,025 \\
\hline Tazmin & 0,516 & 1,94 \\
\hline Özür dileme & 0,539 & 1,855 \\
\hline Kendini ifade etme & 0,572 & 1,748 \\
\hline Bağımlı değişkenler: Marka reddi, NWOM, Marka Öcü & \\
\hline
\end{tabular}

\section{Faktör Analizi Sonuçlarn}

Veriye ilk olarak açılayıcı (AFA) sonrasında da doğrulayıcı faktör analizi (DFA) uygulanmıştır. Açıklayıcı faktör analizi ile toplanan verinin literatürün uygun gördügü şekilde faktör yüklerinin altında toplanıp toplanmadığ kontrol edilmiş, daha sonra da verinin geçerlilik ölçütlerinin kontrolü için veriye doğrulayıcı faktör analizi gerçekleştirilmiştir.

\section{Açıklayıcı Faktör Analizi (AFA)}

Veriye uygulanan Açıklayıcı Faktör Analizinde metot olarak maksimum olabilirlik yöntemi tercih edilmiş, rotasyon metodu olarak ise Promax yöntemi kullanılmıştır. Açklayıcı faktör analizi sonuçlarının değerlendirilmesinde Kaiser-Meyer-Olkin (KMO) degerinin 0,60'ın üzerinde olması (KMO, Kaiser, 1970), Bartlett's Test of Sphericity'nin ise .95 anlamlılık düzeyinde anlamlı olması gerekmektedir (Bartlett's, 1970). Yapılan analizlere göre ilgili koşullar sağlanmaktadır. Analizin KMO değeri 0.858 , anlamlılık degeri ise 0.00 bulunmusțur (Tablo 3). Hattie'ye göre (1985), faktör analizinde boyutları belirlerken, değ̌sskenlerin birbiri ile olan ilișkilerinin \%70'in üstünde olması, hiçbir 
faktörün altında tek degiss,ken olmaması, faktör yuiklerinin ise 0,50 ' nin üzerinde olması ve bir değsskenin birden çok faktör arasında yakın deger almaması gerekmektedir.

Yapılan açıklayıcı faktör analizinde değişkenlerin ölçek maddeleri (marka nefreti, marka reddi, n-WOM, marka öcü) literatürün öngördügü șekilde ilgili faktör yuikleri altında toplanmıs, olup, yedi farklı faktör yükü olușturmuşlardır. Ölçek soruları kendi faktör yuikleri altında toplandığ için ölçeklerle ilgili yeni bir isimlendirme yapılmamıştır. Tüm faktör yükleri 0,50'nin üzerinde değerler almış olup, faktörlerin açılayıcılık oranı \%74,14'tir.

Tablo 3. Açıklayıcı Faktör Analizi ve Güvenilirlik Sonuçları

\begin{tabular}{|c|c|c|c|c|c|c|}
\hline Faktör & Sorular & $\begin{array}{l}\text { Açılanan } \\
\text { Varyans } \\
\text { Oranı }\end{array}$ & $\begin{array}{l}\text { Faktör } \\
\text { Yükleri }\end{array}$ & $\begin{array}{l}\text { Cronbach } \\
\text { Alpha }\end{array}$ & KMO & P (anlamlilık) \\
\hline \multirow{4}{*}{ nWOM } & NWOM3 & 40,52 & 0,894 & 0,908 & \multirow{16}{*}{0,858} & \multirow{16}{*}{0,000} \\
\hline & NWOM2 & & 0,887 & & & \\
\hline & NWOM1 & & 0,876 & & & \\
\hline & NWOM4 & & 0,844 & & & \\
\hline \multirow{5}{*}{$\begin{array}{l}\text { Marka } \\
\text { nefreti }\end{array}$} & Markanefreti 5 & 16,28 & 0,904 & 0,863 & & \\
\hline & Markanefreti 4 & & 0,837 & & & \\
\hline & Markanefreti 2 & & 0,772 & & & \\
\hline & Markanefreti 3 & & 0,76 & & & \\
\hline & Markanefreti 1 & & 0,677 & & & \\
\hline \multirow{4}{*}{ Marka Öcü } & Markaöcü2 & 9,8 & 0,884 & 0,863 & & \\
\hline & Markaöcü 3 & & 0,848 & & & \\
\hline & Markaöcü 1 & & 0,812 & & & \\
\hline & Markaöcü 4 & & 0,81 & & & \\
\hline \multirow{3}{*}{ Marka Reddi } & Markareddi3 & 7,4 & 0,925 & 0,885 & & \\
\hline & Markareddi1 & & 0,857 & & & \\
\hline & Markareddi2 & & 0,846 & & & \\
\hline
\end{tabular}

Extraction Method: Principal Component Analysis. Rotation Method: Promax with Kaiser Normalization.

\section{Doğrulayıcı Faktör Analizi (DFA) ve Geçerlilik Analizleri}

Çalışmada ölçeklerin geçerliliğini test etmek için yakınsama ve ayrım geçerliliği analizlerinden yararlanılmıştır. Yakınsak geçerliliğ için degisskenlere ait standart regresyon ağrlıklarının ve ortalama açılanan varyans (AVE) değerlerinin 0,50'nin üzerinde, yapı güvenilirligĭ degerlerinin (CR) ise, 0,70' in üzerinde olması gerekmektedir (Fornell ve Larcker, 1981). Tablo 4'te göruldügü üzere araștırma olçeginde yer alan tüm değişkenlerin yapı güvenilirliğ 
değerleri (CR) 0.70 değerinin üzerindedir. Yine aynı șekilde ortalama açklanan varyans degerleri (AVE) de 0.50'nin üzerindedir. Dolayısiyla tüm değsskenler için yakınsaklık geçerliliğ kriterleri saglanmaktadır (Hair ve digerleri, 2010).

Modelin ayrım geçerliliğnin ölçümünde Fornell ve Larcker (1981)'in önerdiğ bir faktöre ait ortalama açklanan varyans degerinin (AVE) karekokünün, bu faktörün diger faktölerle olan korelasyon degerinden büyik olması ve MSV degerinin AVE degerinden küçik olması yöntemi kullanılmıştır. Analiz sonucunda elde edilen bulgulara göre modeldeki boyutların ayrı yapılar oldugu ve ayrım geçerliliğnin saglandığ sö̈lenebilir.

Tablo 4.Geçerlilik ve Güvenilirlik Analizi Sonuçlar

\begin{tabular}{llll}
\hline & CR & AVE & MSV \\
\hline WOM & 0,905 & 0,704 & 0,403 \\
\hline REFRET & 0,854 & 0,544 & 0,259 \\
\hline WOM & 0,834 & 0,716 & 0,403 \\
\hline OC & 0,905 & 0,704 & 0,403 \\
\hline
\end{tabular}




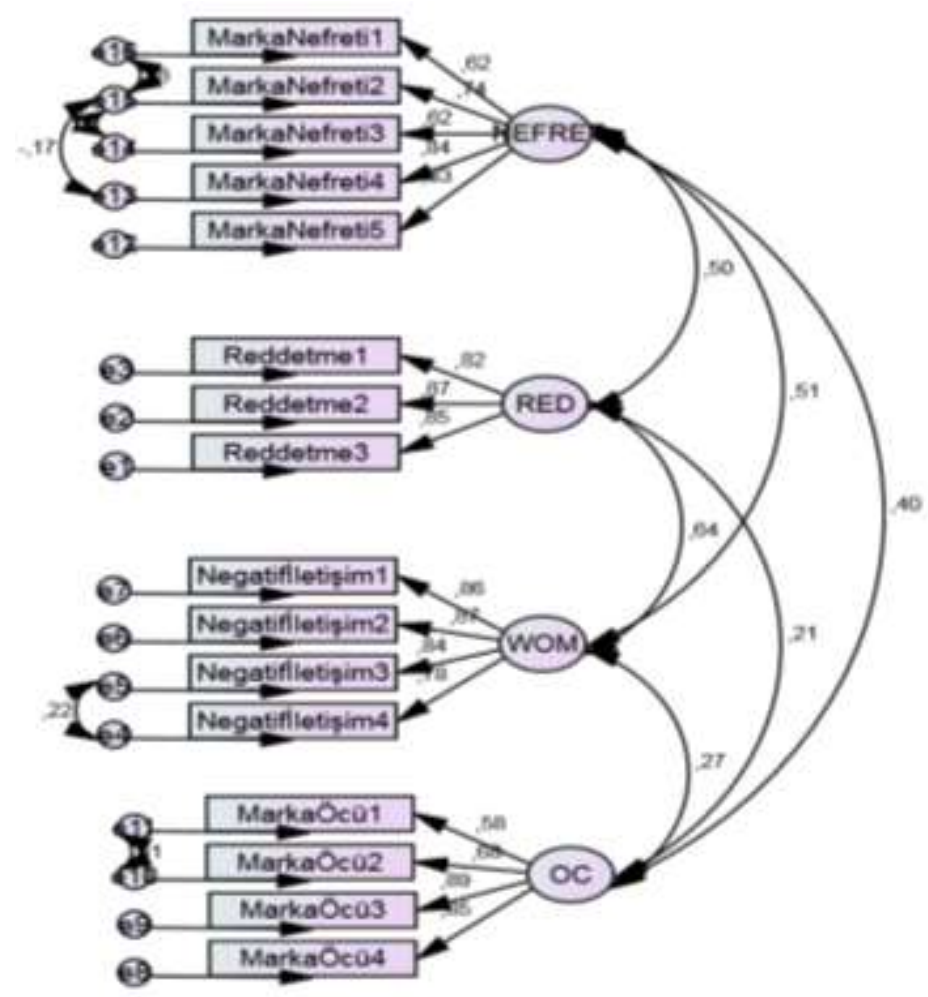

Şekil 3. Doğrulayıcı Faktör Analizi Sonuçları

Yapılan Doğrulayıcı Faktör Analizi sonuçlarına göre, ölçeklerin geçerlilik sonuçları eşik degerlerin üstünde çkmış,ır. Analiz esnasında uyum iyiliği skorlarında daha iyi sonuçlar elde edebilmek için, ayn örtük terimlerin altındaki kovaryanslar (marka nefreti ölçeğinde e13-14, e13-15, e 15-16, negatif ağızdan ağıza ölçeğinde e4-5, marka öcü ölçeğinde ise e10-11) birbirine bağlanmıştır. Açıklayıcı faktör analizi model uyum indislerine göre; marka nefreti, marka reddi, negatif ağızdan ağıza iletişim ve marka öcü değss,kenlerinin faktör yapısının ve model uyum değerlerinin oldukça iyi sonuçlar verdiğ görulmektedir. Tablo 5'teki model uyum degerlerine bakıldığnda, CMIN/DF ( $\chi 2 / s d)$, CFI, PCLOSE değerlerinin iyi, diğr değerlerin ise kabul edilebilir seviyede oldugu göruilmektedir (Hu ve Bentler, 1999). Bu bulgular olçek maddelerinin ilgili boyutlara kabul edilebilir bir uyum göstererek yuiklendiğ s,seklinde yorumlanabilmektedir. 
Tablo 5. Dogrulayıcı Faktö̈ Analizi Uyum Indisleri Tablosu

\begin{tabular}{lll}
\hline Ölçüm & Eşik değerler & Elde edilen değerler \\
\hline$\chi 2 /$ sd $(\mathrm{CMIN} / \mathrm{sd})$ & $<3$ iyi; $<5$ kabul edilebilir & 2,015 \\
\hline Anlamlllık değeri ( $\mathrm{p}$ value) & $>0,05$ & 0,00 \\
\hline CFI & $>0,95$ iyi $>>0,90$ geleneksel, $>0,80$ kabul edilebilir & 0,956 \\
\hline RMR & $<0,09$ & 0,04 \\
\hline RMSEA & $<0,05$ iyi; $0,05-0,10$ orta; $>0,10$ kötü & 0,069 \\
\hline PCLOSE & $>0,05$ & 0,16 \\
\hline
\end{tabular}

\section{Hipotez Testleri}

Araştırma hipotezleri IBM AMOS 24 Programı kullanılarak test edilmiştir. Yapılan yol analizi sonuçlarına göre; marka nefretinin olası sonuçları olarak marka reddi, negatif ağızdan ağıza iletişim ve marka öcü ile ilişkilendirildiği araştırma modelinde, modelin istatistiksel olarak anlamlı olduğu ve modelin uyum indeks değerlerinin kabul edilen eşik değerlerin üzerinde olduğu görülmektedir. Analiz neticesinde elde edilen uyum indeks değerleri Tablo 6'da paylaşılmaktadır $\left(\mathrm{X}^{2} / \mathrm{sd}(\mathrm{CMIN} / \mathrm{sd})=2,538 ; \mathrm{CFI}=0,929\right.$; $\mathrm{RMR}=0,04$; RMSEA= $0,08)$

Tablo 6. Yaptsal Modele ait Uyum İyiliği Değerleri

\begin{tabular}{lll}
\hline Ölçüm & Eşik değerler & Elde edilen değerler \\
\hline$X^{2} / \mathrm{sd}(\mathrm{CMIN} / \mathrm{sd})$ & $<3$ iyi; $<5$ kabul edilebilir & 2,538 \\
\hline Anlamllık değeri $(\mathrm{p}$ value $)$ & $>0,05$ & 0 \\
\hline CFI & $>0,95$ iyi $>>0,90$ geleneksel, $>0,80$ kabul edilebilir & 0,929 \\
\hline RMR & $<0,09$ & 0,04 \\
\hline RMSEA & $<0,05$ iyi; $0,05-0,10$ orta; $>0,10$ kötü & 0,08 \\
\hline PCLOSE & $>0,05$ & 0 \\
\hline
\end{tabular}

Ölçme modelinin doğrulanmasından sonra örtük değişkenli yapısal model üzerinden araştırma hipotezlerinin geriye kalanları test edilmiştir. Ölçme ve yapısal modele ilişkin analiz değerleri Şekil 3 ve Tablo 8 'de gösterilmektedir. 


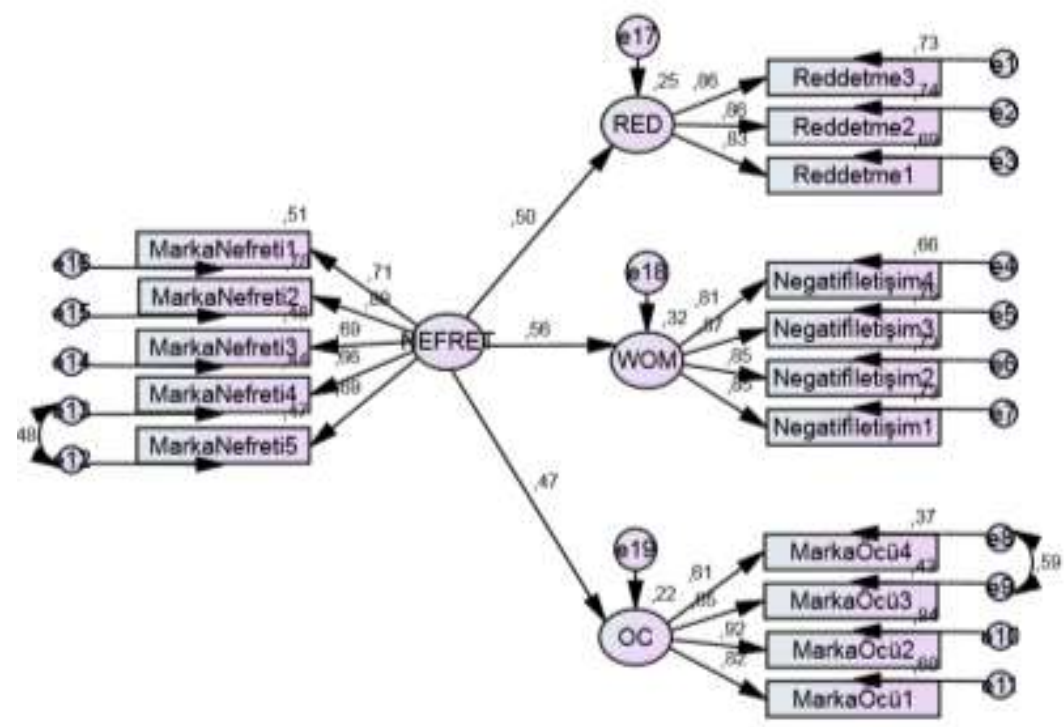

Şekil 4. Araştırma modeline Standardize Yol Diyagram

Analiz sonuçlarına göre, marka nefretinin markayı reddetme $(\beta=0,626$; $p<0,01)$, negatif ağızdan ağıza iletişim $(\beta=0,680 ; p<0,01)$ ve marka öcü $(\beta=0,499$; $p<0,01)$, üzerinde istatistiki olarak anlamlı bir etkisinin olduğu görülmektedir. Bu bulgular doğrultusunda $\mathrm{H}_{1}, \mathrm{H}_{2}$ ve $\mathrm{H}_{3}$ hipotezleri kabul edilmiştir.

Tablo 8. Araştırma modelinin Regresyon Analizi Sonuçlarn

\begin{tabular}{lllllll}
\hline & & & Estimate & S.E. & C.R. & P \\
\hline RED & $<--$ & NEFRET & 0,626 & 0,101 & 6,175 & $* * *$ \\
\hline WOM & $<--$ & NEFRET & 0,68 & 0,1 & 6,774 & $*^{* * *}$ \\
\hline OC & $<--$ & NEFRET & 0,499 & 0,096 & 5,186 & $* * *$ \\
\hline Reddetme2 & $<---$ & RED & 0,951 & 0,065 & 14,561 & $* * *$ \\
\hline Reddetme1 & $<--$ & RED & 0,876 & 0,062 & 14,06 & $* * *$ \\
\hline Negatifilletişim3 & $<--$ & WOM & 0,998 & 0,069 & 14,559 & $* * *$ \\
\hline Negatifilletişim2 & $<--$ & WOM & 1,052 & 0,074 & 14,249 & $* * *$ \\
\hline Negatifilletişim1 & $<--$ & WOM & 1,028 & 0,072 & 14,276 & $* * *$ \\
\hline MarkaÖcü3 & $<---$ & OC & 1,044 & 0,085 & 12,29 & $* * *$ \\
\hline MarkaÖcü2 & $<--$ & OC & 1,41 & 0,152 & 9,27 & $* * *$ \\
\hline MarkaÖcü1 & $<---$ & OC & 1,177 & 0,128 & 9,176 & $* * *$ \\
\hline MarkaNefreti4 & $<---$ & NEFRET & 0,988 & 0,081 & 12,216 & $* * *$ \\
\hline MarkaNefreti3 & $<--$ & NEFRET & 1,064 & 0,118 & 9,042 & $* * *$ \\
\hline MarkaNefreti2 & $<--$ & NEFRET & 1,282 & 0,118 & 10,895 & $* * *$ \\
\hline MarkaNefreti1 & $<--$ & NEFRET & 1,096 & 0,118 & 9,305 & $* * *$ \\
\hline
\end{tabular}


Araştırma modelinde düzenleyici (moderatör) etkiyi ölçümlemek için Yapısal Eşitlik modellemesinde düzenleyici etki analizi gerçekleştirilmiştir. Analize geçmeden, ilk olarak çoklu bağıntı problemi yaşamamak adına tüm değişkenler standardize edilmiştir (z score). Standardize edilen bağımsız değişkenler ile aracı değişkenin (moderatör) çarpılmasıyla etkileşimsel (interaction) değişkenler oluşturulmuş ve analiz yapılarak etkileşimsel etki değişkeninin sonuç değişkeni (bağımlı değişken) üzerinde anlamlı bir etkisinin olup olmadığı test edilmiştir (Gürbüz, 2019, s, 138).

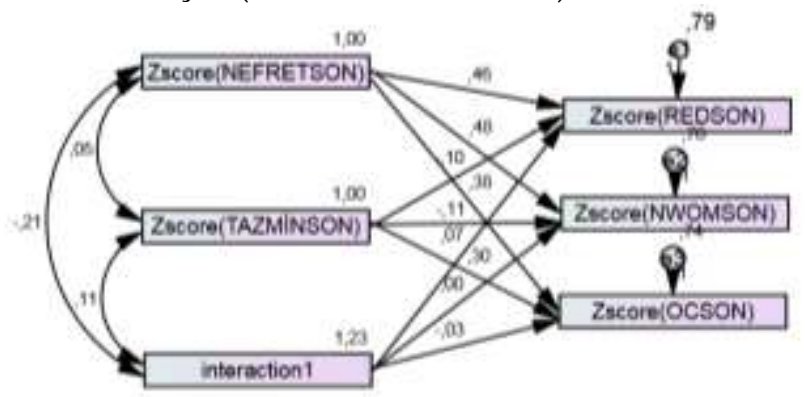

\section{Şekil 5. Marka Nefreti ile Marka Reddi, Negatif Ă̆ızdan Ă̆ıza İletişim ve Marka \\ Öcü arasında Tazmin telafi yönteminin düzenleyici rolüne ait Standardize}

\section{Yol Diyagramı}

Tablo 9'daki regresyon katsayılarına göre modeldeki özellikle aracı etkiyi ölçümleye yarayan etkileşimsel değişkenlerin istatistiki olarak anlamlı olmadığı görülmektedir. Buna göre tazmin ve marka nefretinin çarpılmasıyla oluşan etkileşimsel değişkenin, marka reddine $(\beta=0,06 ; p=0,217)$, negatif ağızdan ağıza iletişime $(\beta=0,00 ; p=0,981)$ ve marka öcüne giderken $(\beta=-0,03 ; p=0,566)$ ilgili değerleri aldığı ve değişkenin modele katkısının istatistiki olarak anlamsız olduğu görülmektedir. Dolayısıyla $\mathrm{H}_{4}, \mathrm{H}_{5}, \mathrm{H}_{6}$ hipotezleri reddedilmiştir.

Tablo 9. Tazmin aracı değişkeni Modeline İlişkin Regresyon Ağırlıklan Sonuçlan

\begin{tabular}{lllllll}
\hline & & & Estimate & S.E. & C.R. & p \\
\hline ZREDSON & $<--$ & ZNEFRETSON & 0,46 & 0,062 & 7,372 & $* * *$ \\
\hline ZREDSON & $<--$ & ZTAZMINSON & $-0,102$ & 0,062 & $-1,659$ & 0,097 \\
\hline ZREDSON & $<--$ & interaction1 & 0,069 & 0,056 & 1,234 & $\mathbf{0 , 2 1 7}$ \\
\hline ZNWOMSON & $<---$ & ZNEFRETSON & 0,482 & 0,061 & 7,883 & $* * *$ \\
\hline ZOCSON & $<---$ & ZNEFRETSON & 0,385 & 0,061 & 6,343 & $* * *$ \\
\hline ZNWOMSON & $<---$ & ZTAZMINSON & $-0,108$ & 0,06 & $-1,782$ & 0,075 \\
\hline ZOCSON & $<--$ & ZTAZMINSON & 0,296 & 0,06 & 4,951 & $* * *$ \\
\hline ZNWOMSON & $<--$ & interaction1 & 0,001 & 0,055 & 0,023 & $\mathbf{0 , 9 8 1}$ \\
\hline ZOCSON & $<--$ & interaction1 & $-0,031$ & 0,055 & $-0,574$ & $\mathbf{0 , 5 6 6}$ \\
\hline
\end{tabular}




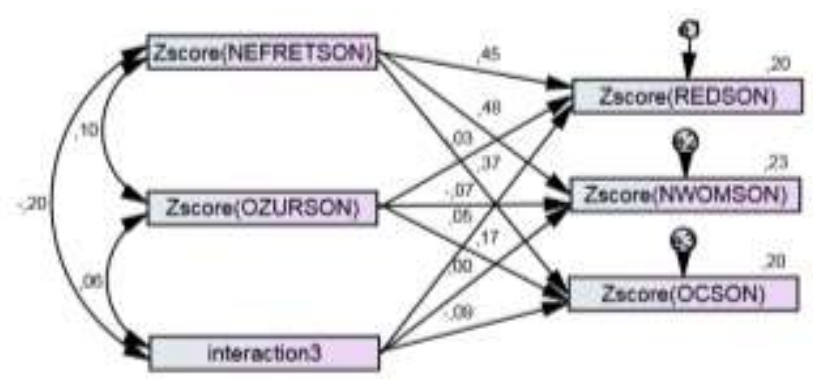

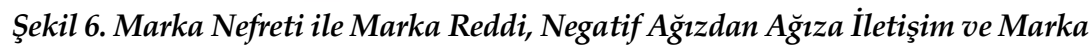
Öcü arasında Özür dileme telafi yönteminin düzenleyici rolüne ait Standardize Yol Diyagramı

Tablo 10'daki regresyon katsayılarına göre modeldeki özellikle aracı etkiyi ölçümleye yarayan etkileşimsel değişkenlerin istatistiki olarak anlamlı olmadığı görülmektedir. Buna göre özür dileme ve marka nefretinin çarpılmasiyla oluşan etkileşimsel değişkenin, marka reddine ( $\beta=0,04$; $p=0,427$ ), negatif ağızdan ağıza iletişime $(\beta=0,02 ; p=0,964)$ ve marka öcüne giderken $(\beta=-$ $0,07 ; p=0,165)$ ilgili değerleri aldığ 1 ve değişkenin modele katkısının istatistiki olarak anlamsız olduğu görülmektedir. Dolayısıyla $\mathrm{H} 7, \mathrm{H}_{8}, \mathrm{H} 9$ hipotezleri reddedilmiştir.

Tablo 10. Özür Dileme Aracı değişkeni Modeline İlişkin Regresyon Ağırlıkları Sonuçlan

\begin{tabular}{lllllll}
\hline & & & Estimate & S.E. & C.R. & P \\
\hline ZREDSON & $<---$ & ZNEFRETSON & 0,453 & 0,063 & 7,174 & $* * * *$ \\
\hline ZREDSON & --- & ZOZURSON & $-0,034$ & 0,062 & $-0,541$ & 0,588 \\
\hline ZREDSON & $<--$ & interaction3 & 0,044 & 0,055 & 0,794 & $\mathbf{0 , 4 2 7}$ \\
\hline ZNWOMSON & $<---$ & ZNEFRETSON & 0,483 & 0,062 & 7,821 & $* * * *$ \\
\hline ZOCSON & $<---$ & ZNEFRETSON & 0,373 & 0,063 & 5,909 & $* * * *$ \\
\hline ZNWOMSON & $<--$ & ZOZURSON & $-0,073$ & 0,061 & $-1,206$ & 0,228 \\
\hline ZOCSON & $<---$ & ZOZURSON & 0,169 & 0,062 & 2,726 & 0,006 \\
\hline ZNWOMSON & $<---$ & interaction3 & $-0,002$ & 0,054 & $-0,045$ & $\mathbf{0 , 9 6 4}$ \\
\hline ZOCSON & --- & interaction3 & $-0,076$ & 0,055 & $-1,387$ & $\mathbf{0 , 1 6 5}$ \\
\hline
\end{tabular}




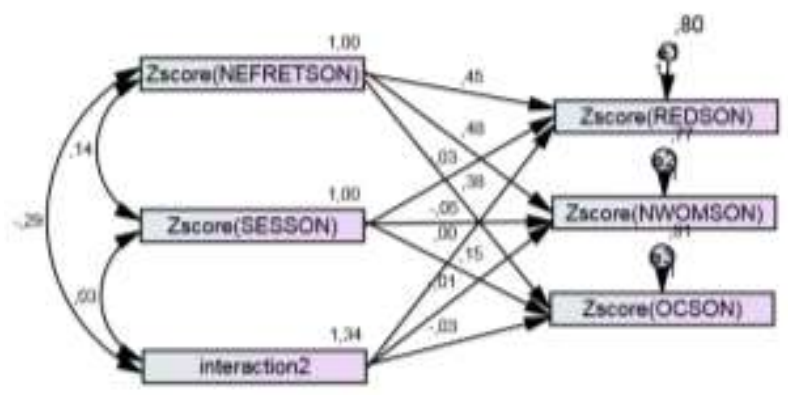

Şekil 7. Marka Nefreti ile Marka Reddi, Negatif Ă̆ızdan Ă̆ıza İletişim ve Marka Öcü arasında Kendini İ fade Etme telafi yönteminin düzenleyici rolüne ait Standardize Yol Diyagramı

Tablo 11'deki regresyon katsayılarına göre modeldeki özellikle aracı etkiyi ölçümleye yarayan etkileşimsel değişkenlerin istatistiki olarak anlamlı olmadığı görülmektedir. Buna göre kendini ifade etme ve marka nefretinin çarpılmasıyla oluşan etkileşimsel değişkenin, marka reddine $(\beta=0,00 ; p=0,959)$, negatif ağızdan ağıza iletişime $(\beta=-0,01 ; \beta=0,836)$ ve marka öcüne giderken $(\beta=-$ 0,$02 ; p=0,621$ ) ilgili değerleri aldığı ve değişkenin modele katkısının istatistiki olarak anlamsız olduğu görülmektedir. Dolayısıyla $\mathrm{H}_{10}, \mathrm{H}_{11}, \mathrm{H}_{12}$ hipotezleri reddedilmiştir.

Tablo 11. Kendini İfade Etme Aracı Değişkeni Modeline İlişkin Regresyon Ağırlıkları Sonuçlar

\begin{tabular}{lllllll}
\hline & & & Estimate & S.E. & C.R. & P \\
\hline ZREDSON & ---- & ZNEFRETSON & 0,445 & 0,064 & 6,917 & $* * *$ \\
\hline ZREDSON & ---- & ZSESSON & $-0,031$ & 0,062 & $-0,5$ & 0,617 \\
\hline ZREDSON & $<--$ & interaction2 & 0,003 & 0,055 & 0,052 & 0,959 \\
\hline ZNWOMSON & $<--$ & ZNEFRETSON & 0,481 & 0,063 & 7,644 & $* * *$ \\
\hline ZOCSON & ---- & ZNEFRETSON & 0,378 & 0,065 & 5,835 & $* * *$ \\
\hline ZNWOMSON & $<---$ & ZSESSON & $-0,055$ & 0,061 & $-0,897$ & 0,37 \\
\hline ZOCSON & $<---$ & ZSESSON & 0,146 & 0,063 & 2,326 & 0,02 \\
\hline ZNWOMSON & --- & interaction2 & $-0,011$ & 0,054 & $-0,208$ & 0,836 \\
\hline ZOCSON & ---- & interaction2 & $-0,027$ & 0,055 & $-0,494$ & 0,621 \\
\hline
\end{tabular}

\section{Sonuç}

Günümüzde marka aşkı gerek akademik gerekse de pratik iş dünyasında tansiyonu yüksek bir konu olarak üst sıralarda yerini korusa da marka aşk1- 
nın zıddı olan marka nefreti de tüketicilerin belirli ürün gruplarına ve markalarına karşı yaşadığı negatif bir durum olarak pazarlama teorisyenleri ve pratisyenlerinin dikkat kesildiği yeni dönem konu başlıklarından biridir.

Çalışmamızda literatür ışığında marka nefretinin olası sonuçları gözlemlenmiştir. Araştırma bulgularına göre tükettiği marka ile nefret boyutuna gelmiş negatif bir ilişki yaşayan tüketicilerde, markayı reddetme, marka ile ilgili etrafındaki kişilere negatif yönde iletişim yapma (nWOM) ve markanın ürün ve/veya hizmetlerine karşı bilinçli bir şekilde zarar verme eğilimi olarak adlandırılan markadan öç alma durumlarının geliştiği görülmüştür. Bulgulara göre marka nefreti yaşayan tüketiciler, ilk sırada marka ile ilgili negatif iletişim (nWOM) yapmakta, negatif iletişimi de markayı reddetme ve markadan öç alma gibi eylemlerin takip ettiği görülmektedir. Bununla beraber literatürde yapılan araştırmalar tüketicilerde bağışlama söz konusu olduğunda, nefret ettiği markaya karşı hissettikleri negatif düşünceler, hisler ve davranışların azalabileceği (McCullough ve diğerleri, 2000; Worthington, 2005) ve tüketicilerin daha az negatif WOM yapma eğiliminde olabilecekleri yönündedir (Tsarenko ve Tojib, 2011). Dolayısıyla araştırmamızda işletmeler tarafından verilebilecek bazı telafi stratejilerinin marka nefreti ile olası sonuçları arasındaki ilişkide düzenleyici bir etkisi olup olamayacağı araştırılmıştır. Araştırmamızın sonuçları; tazmin, özür dileme ve kendini ifade etme telafi stratejilerinin marka nefreti ve olası sonuçları arasındaki ilişkide düzenleyici bir etkisinin olmadığ1 yönündedir. Buradan hareketle tüketicinin nefret boyutunda bir ilişki yaşadığı markadan, ne türlü bir telafi hizmeti alırsa alsın, kuvvetli bir negatif duygu olan nefretin süreçte hakim geldiği ve müşteriyi eski tutumuna döndüremediği yönündedir. Dolayısıyla işletmelerin proaktif bir yaklaşımla tüketicisiyle satın alma öncesi, sırası ve sonrasında yaşayabileceği her türlü problemi minimuma indirmesi ve hatta yaşanmaması için maksimum çaba sarf edecek şekilde davranması öncelikli bir yaklaşım olarak önem arz etmektedir. Pek çok akademisyenin de belirttiği gibi nefret kavramı durağan ve uzun dönemli bir duygudur (Ben-Ze'ev, 2000; Rempel ve Burris, 2005; Royzman, 2004; Weingarten, 2006). Bir kere yaşanması durumunda mevcut müşterinin kaybedilmesi, uzun süre geri kazanılamaması ve ilgili müşterinin şikayet yoluyla mutsuzluğunu çevresindekilerle paylaşması gibi nedenlerden ötürü, işletmeyi hem kısa hem de uzun vadede finansal (satış kaybı) ve finansal olmayan (marka değeri kaybı) değer kaybına uğratacaktır. 


\title{
EXTENDED ABSTRACT
}

\section{Moderation Effect of Recovery Strategies on the Relationship Between Brand Hate and Its Possible Outcomes}

\author{
* \\ Müge Örs - Melis Kaytaz Yiğit \\ Istanbul Aydin University, Avrasya University
}

The concept of brand hate was brought to the marketing literature by Grégoire et al. (2009) for the first time and the authors defined brand hate as a form of desire for revenge or desire for avoidance. In the marketing literature, studies that can be associated with brand hate are generally grouped under three main headings. The first one, is the studies that deal with the negative relationships between the consumer and the brand (Fournier ve Alvarez, 2013; Park, Eisingerich ve Park, 2013). The second is the studies on antibrand communities, which often reveal the view that consumers gathering in line with the negative feelings they have with the brand and share their negative experiences with other consumers and even set a common action plan (Hollenbeck ve Zinkhan, 2010; Krishnamurthy ve Küçük, 2009). The third one is the studies that involve the service errors that occur as a result of the negative experiences of the consumers with the service providers, especially in service marketing (Grégoire, Tripp ve Legoux, 2009; Johnson, Matear ve Thomson, 2011).

In researches on brand hate, brand hate is classified as passive brand hate (brand rejection, brand switching) and active brand hate (negative word of mouth communication and brand revenge) (Hegner, Fetscherin ve Delzen, 2017). In our study, both active and passive brand hate results are examined in terms of recovery strategies.

Brand rejection occurs when consumers consciously choose to stay away from a brand or reject it (Grégoire vd., 2009; Lee vd., 2009, Park vd., 2013; Zarantonello, Romani, Grappi ve Bagozzi, 2016). Lee et al. (2009) stated the main reasons for consumers' experience in brand rejection and/or avoidance as the negative experiences of consumers with products and services, the 
identity mismatches with the brand, the benefit-cost deficit and the ethical and ideological mismatch that consumers live with the product/brand.

Negative WOM is defined as the consumer sharing the negative experiences of the product or services with their environment. It is also known that consumers are willing to share their negative experiences compared to her positive experiences (Singh, 1988; Baumeister, Bratslavsky, Finkenauer ve Vohs, 2001).

Brand retaliation is one of the strongest outcomes of brand hate. Grégoire et al. (2010) define brand retalization as an output of brand hate and Sternberg (2003) states that brand hate is fed by the revenge. Grégoire et al. (2010) mention that consumers want to punish and deliberately harm hated brands in order to take a revenge.

Consumer forgiveness is possible with the recovery strategies offered to them by the companies. Recovery strategies emerge when there are some deficiencies, errors or inconvenient situations that companies experience with their consumers regarding its products or services (Gronroos, 2000; Johnston ve Mehra, 2002). Recovery strategies are generally shaped as apology, compensation and voice (Hui ve $\mathrm{Au}, 2001$ ).

The aim of the study is to examine the possible outcomes of brand hate in the light of literature and measuring the mediating effect of recovery strategies. The theoretical significance of the research is being a first time study that the subject has been addressed in the context of recovery strategies. The practical importance of the research is aiming to show the marketing professionals the possible results of the brand hate and emphasizing the importance of developing proactive strategies in the context of not creating brand hate.

The study is a quantitative descriptive study and it is reached to 213 consumers who had hate relationship with brands. Convinient sampling method was used and the data obtained were subjected to data analysis such as Explanatory, Confirmatory Factor Analysis and Path Analysis using statistical package programmes of SPSS 19 and AMOS 23.

The findings of the study indicate that consumers who have a brand hate are showing respectively negative word of mouth, brand rejection and brand retaliation. In addition, it is revealed that recovery strategies (apology, compensation and voice) put forward by companies can not decreasing the relationship between brand hate and brand rejection, retaliation or negative communication behaviors of consumers (nWOM). From this point of view, it is 
seen that no matter what kind of compensation service the consumer receives from the hated brand prevails in the process (as hate is the strongest negative emotion) and is unable to return the cosumers to their former attitude. Therefore, it is crucial as a priority developing a proactive approach for companies to minimize any problems that they may be experienced before, during and /or after purchasing with their consumers and even act in maximum effort to avoid them. As it is observed, if the brand hate is experienced once, due to reasons such as the loss of the existing customer, not being regained for a long time and customer complaints blocking new potantial customers gain, the company will lose financial (loss of sales) and non-financial (loss of brand value) value both in the short and long term.

\section{Kaynakça / References}

Alba, J.W. ve Lutz, R.J. (2013). Broadening (and narrowing) the scope of brand relationships. Journal of Consumer Psychology, 23(2), 265-268.

Albert, N., Merunka, D., ve Valette-Florence, P. (2008). When consumers love their brands. Exploring the concept and its dimensions. Journal of Business Research, 61(10), 1062- 1075.

Bagozzi, R. Ve Yi, Y. (1988). On the evaluation of structural equation models. Journal of the Academy of Marketing Science, 16, 74-94.

Barlow, J. ve Moller, C. (1996). A complaint is a gift: Using customer feedback as a strategic tool. San Francisco: Berrett-Koehler.

Baruönü Latif F. Ö and Uslu A. (2019). Building e-loyalty for e-retailers: role of justice perception and consumer forgiveness. Middle East J. Management, 6(3), 298-317

Batra R, Ahuvia A. ve Bagozzi R (2012) Brand love.Journal of Marketing, 76(2) 1-16. Baumeister, R., Bratslavsky, E., Finkenauer, C. and Vohs, K. (2001). Bad is stronger than good. Review of General Psychology, 5, 323-370.

Ben-Ze'ev, A. (2000). The subtlety of emotions. Cambridge: MA: MIT Press. http://books.google.nl/books?hl=nl\&lr=\&id=SOrkL_Unl-

cC\&oi=fnd\&pg=PR11\&dq=BenZe\%E2\%80\%99ev,+A.+(2000).+The+subtlety+of+emotions.+Cambridge,+MA:+MIT+Press.\&ots= mebM0zLvlK\&sig=i7-St2AbJNjG1wxu_r8EiUHSf2 $\mathrm{c} \# \mathrm{v}=$ onepage\&q=Ben-

Ze\%E2\%80\%99ev\%2CCambridge\%2CMA\%3AMIT Press.\&f=false adresinden erişilmiştir. 
Bennett, R. (1997). Anger, catharsis, and purchasing behavior following aggressive customer complaints. Journal of Consumer Marketing, 14(2), 156-172.

Bitner, M. J., Booms, B. H. ve Tetreault, M. S. (1990). The service encounter: Unfavorable incidents. Journal of Marketing, 54, 71-84.

Blodgett, J. G., Granbois, D. H. ve Walters, R. G. (1993). The effects of perceived justice on complainants' negative word-of-mouth behavior and repatronage intentions. Journal of Retailing, 69(4), 399-428.

Breivik, E. Ve Thorbjørnsen, H. (2008). Consumer brand relationships: an investigation of two alternative models. Journal of the Academy of Marketing Science, 36(4), 443-472.

Bryson, D., Atwal, G. ve Hultén, P. (2013). Towards the conceptualisation of the antecedents of extreme negative affect towards luxury brands. Qualitative Market Research: An International Journal, 16, 393-405.

Carroll, B. ve Ahuvia, A. (2006). Some antecedents and outcomes of brand love. Marketing Letters, 17, 79-89.

Casidy, R. and Shin, H. (2015). The effects of harm directions and service recovery strategies on customer forgiveness and negative word-of-mouth intentions. Journal of Retailing and Consumer Services, 27, 103-112.

Cherrier, H. (2009). Anti-consumption discourses and consumer-resistant identities. Journal of Business Research, 62, 181-190.

Christodoulides, G., Jevons, C. ve Bonhomme, J. (2012). Memo to marketers: quantitative evidence for change. Journal of Advertising Research, 52(1), 53-64.

Conlon, D. E. ve Murray, N. M. (1996). Customer perceptions of corporate responses to product complaints: The role of explanations. Academy of $M a-$ nagement Journal, 39(4), 1040-1056.

Cottle, D. (1990). Client-centred service. Chichester: Wiley.

Cromie, J. ve Ewing, M. (2009). The rejection of brand hegemony. Journal of Business Research, 62, 218-230.

Dalli, D., Romani, S. ve Gistri, G. (2006). Brand dislike: Representing the negative side of consumer preferences. Advances in Consumer Research, 33, 87-95.

Dessart, L., Morgan-Thomas, A. ve Veloutsou, C. (2016). What drives anti-brand community behaviours: an examination of online hate of technology brands. Obal, M.W., Krey, N. ve Bushardt, C. (Eds), Let's Get Engaged! Crossing the Threshold of Marketing's Engagement Era içinde (s.473-477), Springer International Publishing,

Fehr, B. ve Russell, J. (1984). Concept of emotion viewed from a prototype perspective. Journal of Experimental Psychology, 113, 464-486. 
Fetscherin, M. ve Heinrich, D. (2014). Consumer Brand Relationships Landscape. Journal of Brand Management, 21(5), 366-371.

Fournier, S. ve Alvarez, C. (2013). Relating badly to brands. Journal of Consumer Psychology, 23(2), 253-264.

Gelbrich, K., Gathke, J. ve Gregoire, Y. (2013). How much compensation should a firm offer for a flawed service? An examination of the nonlinear effects of compensation on satisfaction. Journal of Service Research, 18(1), 107-123.

Goodwin, C., ve Ross, I. (1992). Consumer responses to service failure: Influence of pro- cedural and interactional fairness perceptions. Journal of Business Research, 25(2), 149-163.

Grégoire, Y., Laufer, D. ve Tripp, T. (2010). A comprehensive model of customer direct and indirect revenge: understanding the effects of perceived greed and customer power. Journal of the Academy of Marketing Science, 38,738-758.

Grégoire, Y., Tripp, T. ve Legoux, R. (2009). When customer love turns into lasting hate: the effects of relationship strength and time on customer revenge and avoidance. Journal of Marketing, 73,18-32.

Gronroos, C. (2000). Service management and strategy: Marketing the moments of truth in service competition (2nd ed.). Lexington, MA: Lexington Books.

Gürbüz, Sait, (2019), AMOS ile yapısal eşitlik modellemesi, temel ilkeler ve uygulamal analizler, Ankara:Seçkin Yayınevi,

Hair, Jr., Anderson, J. F., Tatham R. E. ve Black, W. C. (2010), Multivariate data analysis. 5th ed. New Jersey: Prentice Hall

Harrison-Walker, L. J. (2019). The critical role of customer forgiveness in successful service recovery, Journal of Business Research, 95, 376-391

Hart, C. W., Heskett, J. L. ve Sasser, W. E. (1990). The profitable art of service recovery. Harvard Business Review. 68(July/August), 148-156

Hirschman, A. O. (1970). Exit, voice, and loyalty: Responses to declines in firms, organizations, and States. Cambridge, MA: Harvard University Press.

Hoffman, K. D., Kelley, S. W. ve Chung, B. C. (2003). A CIT investigation of service scape failures and associated recovery strategies. Journal of Services Marketing, 17(4), 322-340.

Hogg, M. (1998). Anti-constellations: exploring the impact of negation on consumption. Journal of Marketing Management, 14, 133-158.

Hollenbeck, C.R. ve Zinkhan, G.M. (2010). Anti-brand communities, negotiation of brand meaning, and the learning process: the case of Wal-Mart. Consumption, Markets and Culture,13(3), 325-345. 
Hsu, C.L., Yu, L.C. ve Chang, K.C. (2017). Exploring the effects of online customer reviews, regulatory focus, and product type on purchase intention: perceived justice as a moderator. Computers In Human Behavior, 69, 335-346.

Hu, L. T., ve Bentler, P. M. (1999). Cutoff criteria for fit indexes in covariance structure analysis: Conventional criteria versus new alternatives. Structural equation modeling: a multidisciplinary journal, 6(1), 1-55.

Hui, M. K. ve Au, K. (2001). Justice perceptions of complaint-handling: A crosscultural comparison between PRC and Canadian customers. Journal of Business Research, 52, 161-173.

Inyang, A. E. (2015). The buffering effects of salesperson service behaviors on customer loyalty after service failure and recovery. Journal of Managerial Issues, 27(1-4).

Iyer, R. ve Muncy, J. (2009). Purpose and object of anti-consumption. Journal of Business Research, 62(2), 160-168.

Johnson, A.R., Matear, M. ve Thomson, M. (2011). A coal in the heart: self-relevance as a post-exit predictor of consumer anti-brand actions. Journal of Consumer Research, 38(1), 108-125.

Johnston, R. R. ve Mehra, S. (2002). Best practice complaint management. Academy of Management Executive, 16(4), 145-154.

Kelly, S. W., Hoffman, D. ve Davis, M. A. (1993). A typology of retail failures and re- coveries. Journal of Retailing, 69(4), 429-452.

Khan, M. ve Lee, M. (2014). Prepurchase determinants of brand avoidance: the moderating role of country-of-origin familiarity. Journal of Global Marketing, 27, 329-343

Krishnamurthy, S. ve Kucuk, S.U. (2009). Anti-branding on the internet. Journal of Business Research, 62(11), 1119-1126.

Kucuk, S.U. (2008). Negative double jeopardy: the role of anti-brand sites on the internet. Journal of Brand Management,15, 209-222.

Laros, F. J. M. ve Steenkamp, J. E. M. (2005). Emotions in consumer behavior: A hierarchical approach. Journal of Business Research, 58(10), 1437-1445

Lee, M. S. W., Motion, J. ve Conroy, D. (2009). Anti-consumption and brand avoidance. Journal of Business Research, 62(2),169-180.

Liao, S., Chou, C. Y. ve Lin, T., (2015). Adverse behavioral and relational consequences of service innovation failure. Journal of Business Research, 68(4), 834839. 
McCullough, M. E., Rachal, K. C., Sandage, S. J., Worthington, E. L., Jr., Brown, S. W. ve Hight, T. L. (1998). Interpersonal forgiving in close relationships: II. Theoretical elaboration and measurement. Journal of Personality and Social Psychology, 75, 1586-1603.

Middle East J. Management, (2019). Building e-loyalty for e-retailers: role of justice perception and consumer forgiveness. Vol. 6, No. 3

Monga, A. (2002). Brand as a relationship partner: gender differences in perspectives. Advances in Consumer Research, 29 (1), 36-41.

Nenycz-Thiel, M. ve Romaniuk, J. (2011). The nature and incidence of private label rejection. Australasian Marketing Journal, 19, 93-99.

Nyer, P. ve Gopinath, M. (2005). Effects of complaining versus negative word of mouth on subsequent changes in satisfaction: the role of public commitment. Psychology \& Marketing, 22, 937-953.

Oliva, T., Oliver, R. ve MacMillan, I. (1992). A catastrophe model for developing service satisfaction strategies. The Journal of Marketing, 56(July), 83-95.

Park, C., Eisingerich, A. ve Park, J. (2013). Attachment- aversion (AA) model of customer-brand relationships. Journal of Consumer Psychology, 23, 229248.

Presi, C., Saridakis, C. ve Hartmans, S. (2014). User-generated content behaviour of the dissatisfied service customer, European Journal of Marketing, 48 Nos, 9(10), 1600-1625

Rempel, J. K. ve Burris, C. T. (2005). Let me count the ways: An integrative theory of love and hate. Personal Relationships, 12(2), 297-313.

Rindell, A., Strandvik, T. ve Wilén, K. (2014). Ethical consumers' brand avoidance. Journal of Product and Brand Management, 23,114-120.

Romani, S., Grappi, S.ve Dalli, D. (2012). Emotions that drive consumers away from brands: measuring negative emotions toward brands and their behavioral effects. International Journal of Research in Marketing, 29, 55-67.

Romani, S., Sadeh, H. ve Dalli, D. (2009). When the brand is bad, I'm mad! An exploration of negative emotions to brands. Advances in Consumer Research, 36, 494-501.

Royzman, E. B., McCauley, C. ve Rozin, P. (2005). From Plato to Putnam: Four Ways to Think About Hate. R. J. Sternberg (Ed.), The psychology of hate içinde (s.3-35). American Psychological Association. https://doi.org/10.1037/10930-001 
Ruiz-Mafe, C., Aldas-Manzano, J. ve Veloutsou, C. (2015). Understanding and Managing Negative eWom: The role of trust, dissatisfaction and negative brand relationships. 10th Global Brand Conference, Turku, Finland, 27-29 Apr 2015, (Unpublished)

Hegner, S. M., Fetscherin, M. ve van Delzen, M., (2017). Determinants and outcomes of brand hate. Journal of Product \& Brand Management, 26 (1), 13-25

Sampedro, A. (2017). Brand hate and brand forgiveness: A dynamic analysis. Honors Program Theses, Rollins College Rollins Scholarship Online, https://scholarship.rollins.edu/cgi/viewcontent.cgi?article $=1053 \&$ context=honors adresinden erişilmiştir.

Sandıkcı, O: ve Ekici, A. (2009). Politically motivated brand rejection. Journal of Business Research, 62, 208-217.

Sarkar, A. ve Sreejesh, S. (2014). Examination of the roles played by brand love and jealousy in shaping customer engagement. Journal of Product $\mathcal{E}$ Brand Management, 23, 12-22

Shaver, P., Schwartz, J., Kirson, D. ve O'Connor, C. (1987). Emotion knowledge: further exploration of a prototype approach. Journal of Personality and Social Psychology, 52, 1061-1086.

Singh, J. (1988). Consumer complaint intentions and behavior: definitional and taxonomical issues. Journal of Marketing, 52, 93-107.

Sipahi, B., Yurtkoru, E.S., Çinko,M. (2010). Sosyal bilimlerde SPPSS'le veri Analizi. 3. Baskı, İstanbul:Beta yayınları.

Smith, A. K., Bolton, R. N. ve Wagner, J. (1999). A model of customer satisfaction with service encounters involving failure and recovery. Journal of Marketing Research, 36 (August), 356-372.

Sternberg, R. J. (2003). A duplex theory of hate: Development and application to terrorism, massacres, and genocide. Review of General Psychology, 7, 299328.

Sternberg, R.J. (1986). A triangular theory of love. Psychological Review, 93(2), 119135.

Tax, S. S., Brown, S. W. ve Chandrashekaran, M. (1998). Customer evaluations of service complaint experiences: Implications for relationship marketing. Journal of Marketing, 62(2), 60-76.

Thomson, M., Whelan, J. ve Johnson, A. (2012). Why brands should fear fearful consumers: how attachment style predicts retaliation. Journal of Consumer Psychology, 22, 289-298. 
Tsarenko, Y. ve Tojib, D. (2011). A transactional model of forgiveness in the service failure context. Journal of Services Marketing, 25(5), 381-392.

Vazques-Casielles, R., Iglesias, V. ve Varela-Neira, C. (2012). Service recovery, satisfac- tion, and behavioral intentions: Analysis of compensation and social comparison communication strategies. The Service Industries Journal, 32(1), 83-103.

Walster, E., Berscheid, E. ve Walster, G. W. (1973). New directions in equity research. Journal of Personality and Social Psychology, 25(2), 151-176.

Weingarten, K. (2006). On hating to hate. Family process, 45(3), 277-88.

Wolter, J.S., Brach, S., Cronin, J.J. ve Bonn, M. (2016). Symbolic drivers of consumer-brand identification and disidentification. Journal of Business Research, 69(2),785-793

Worthington, E. L., Jr. (2005). Handbook of forgiveness. New York: Brunner-Routledge Press.

Yuksel, U. ve Mryteza, V. (2009). An evaluation of strategic responses to consumer boycott. Journal of Business Research, 62, 248-259.

Zarantonello, L., Romani, S., Grappi, S. ve Bagozzi, R. (2016). Brand hate. Journal of Product \& Brand Management, 25(1), 11-25.

Zeithaml, V., Berry, L. ve Parasuraman, A. (1996). The behavioral consequences of service quality. Journal of Marketing, 60, 31-46.

\section{Kaynakça Bilgisi / Citation Information}

Örs, M. ve Kaytaz Yiğit, M. (2020). Marka nefreti ve olası sonuçları üzerinde işletme telafi süreçlerinin düzenleyici etkisi. OPUS-Uluslararası Toplum Araştırmaları Dergisi, 15(26), 4101-4133. DOI: 10.26466/opus.676294 